ACTA THERIOLOGICA

Vol. 31, 36: 491-506, 1986

\title{
Diet of Foxes and Martens in Central Poland
}

\author{
Jacek GOSZCZYNSKI
}

Goszczyński J., 1986: Diet of foxes and martens in central Poland. Acta theriol., 31, 36: 491-506 [With 2 Tables \& 8 Figs.]

The diet of foxes and martens was examined on the basis of the composition of their feaces (1139 and 813 portions, respectively) collected from the same area in central Poland. Although the mean density of the common vole was low in the study area, an increase in the number of these rodents was followed by a functional response of both foxes and martens. This response, however, was weaker than in the areas with a high abundance of voles. The proportion of voles in the diet was more variable in the study area than in the areas of their high densities. In the diet of foxes, three groups of food items were found in similar proportions (about $26-33 \%$ by weight): small mammals, birds, and hares. In foxes a compensatory response was found between the consumption of small mammals, on the one hand, and birds and hares, on the other. Martens consumed the same three groups of prey; but also fruits were an important component of their diet $(37 \%)$. Except for small mammals preyed upon by martens throughout the year, the other food items (hares, birds, insects, and fruits) were consumed from time to time. Martens showed a compensatory response between preying on small mammals and eating fruits in summer and autumn months, and also between preying upon small mammals and birds in winter and spring months. The diet of foxes was characterized by a small annual variation and a high seasonal variation in the study area as compared with areas supporting high vole densities.

[Warsaw Agricultural University, Faculty of Forestry, Department of Game iManagement, Rakowiecka 26/30, 02-528 Warsaw, Poland]

\section{INTRODUCTION}

Foxes Vulpes vulpes (Linnaeus, 1758) and martens Martes martes (Linnaeus, 1758) and Martes foina (Erxleben, 1777) are opportunistic predators clearly responding to changes in the available food supply. An analysis of the diet of these three predators in the same area makes it possible to estimate differences between them in the intensity of functional response. The aim of this paper was to examine not only the general composition of food of these predators but also its seasonal and long-lerm variation. Moreover, as the study was conducted in the area of a low common vole, Microtus arvalis (Pallas, 1779) population,

Praca wykonana w ramach problemu MR.II.19, koordynowanego przez SGGW-AR w Warszawie. 
it was possible to compare the present results with earlier literature data on the diet of foxes and martens in the areas of high vole populations.

\section{STUDY AREA}

The study was carried out in the region of Rogów $\left(51^{\circ} 48^{\prime} \mathrm{N}, 19^{\circ} 53^{\prime} \mathrm{E}\right)$, Skierniewice province, central Poland, in 1978-1985. Forests, physiographically distinguished in the form of nonfragmented units in croplands, accounted for about $21 \%$ of the study area. Waste land, buildings and roads covered about $6 \%$, meadows and pastures about 5\%. Crop plants were dominated by rye and potatoes. Alfalfa and clover, which provide important habitats for common voles, covered only one per cent of the study area. Farming was of extensive character. Crop fields were small, averaging less than 1 ha, and crossed by a network of roads and balks. The highest densities of the common vole reached about 80 individuals/ha (Goszczyński, 1985). Forests were dominated by the bank vole Clethrionomys glareolus (Schreber, 1780), reaching peak numbers in 1983 (Babinska-Werka, pers. comm.). The densities of larger animals were moderate. Hares Lepus capensis Linnaeus, 1758 reached a density of $12-15$ individuals/100 ha in autumn (Goszczyński, 1985), partidges Perdix perdix (Linnaeus, 1758) 15-23 individuals/100 ha (Dudziński, pers. comm.), pheasants Phasianus colchicus (Linnaeus, 1758) 6-11 individuals/100 ha (Wasilewski, pers. comm.).

\section{METHODS AND MATERIAL}

The food of foxes and martens was examined for living animals by analysing their feaces. Each portion of feaces was put on a sieve and washed with water to remove the external substances (sand, soil, needles, etc.) and amorphous components. The clean material remaining on the sieve was sorted such groups being distinguished as for example small rodents, hares, birds, insects, fruits, etc., on the basis of fur, fragments of skeleton, feathers, chitin, husk, stones of fruit, etc. Moreover small mammals were identified to species using their teeth found in analysed scats. The sorted material was air-dried to a constant weight, and weight of each group was multiplied by a factor characterizing their coefficient of digestibility (see Lockie, 1959; Goszczyński, 1974, 1976). In this paper I used the coefficients given in earlier papers (Goszczyński, 1974; Goszczyński, 1976). In the case of the carrion of dogs, wild boars, and sheep, a factor of 118 was used, that is, the same as for roe deer carrion. In the case of cats sporadically consumed by predators, a factor of 50 was used, the same as for hares. The weights of different food items that 
were not digested multiplied by respective coefficients give the total weight of the food consumed.

Percentage by weight of individual groups in the diet of foxes and martens was calculated as a ratio of the biomass of a given food category to the total biomass consumed. Further subdivision within the group of small mammals was made on the basis of the number of prey consumed and their mean body weight to estimate the percentage by weight for individual species in the food.

Feaces were collected from the autumn of 1978 to the winter of 1985 , thus over 26 seasons. The number of scats of foxes collected in the summer months of 1979,1980 and 1982 was unsufficient for diet analysis, thus the analysis covers 23 seasons. The diet of martens was analysed for all the 26 seasons. On the averge, 48 scats were analysed for foxes and 31 for martens in each season. The total number of scats analysed was 1139 for foxes and 813 for martens.

As it was impossible to distinguish scats of the stone marten from those of the pine marten, and both these species occurred in the study area, they were analysed jointly.

Besides fecal analyses, some additional methods were used: (1) Winter tracking of foxes and martens and registration of encountered remains of their prey; (2) Collecting prey remains in the field during all the seasons. Characteristic traces of foraging or feaces left on prey remains permitted the identification of the predator in many cases; (3) Analyses of stomach contents of the foxes killed by local hunters on the study area, and (4) Inspection of fox burrows during the breeding period, and collecting prey remains near burrows.

Any of these four methods could not be used separately since typically they were limited to certain seasons of the year (methods 1,3 and 4), provided scarce material (methods 2 and 3), and, moreover, not always adequatly reflected the diet of the predator (method 1 and 4). For example, winter tracking permits the recording of the frequency of attacks on individuals or groups of prey, but does not always inform whether the attack was successful because not always fur or blood is left in the case of successful attack. Similar shortcomings are valid for inspection of fox burrows, where the remains of small prey are rare, as typically they are consumed as a whole, immediately upon being brought to the burrow. Hence, although 380 prey remains were collected around burrows over a period of six years, this material was of the limited usefulness because the remains of large prey were highly overrepresented in it.

In view of these difficulties, the above methods were used only for estimating the biomass of individual bird species. The total proportion 
of birds in the diet of predators was estimated from fecal analyses, but a more detailed analysis of this group is difficult because the parts of the remains permitting the identification to species, such as claws or fragments of skulls, are rarely encountered. For this purpose the above mentioned additional methods permitting legs and feather identigiven species (number of occurrences $\times$ mean body weight) to the total biomass of bird prey was calculated as a ratio of the biomass of a given species (number of occurrences $x$ mean body weight) to the total biomass of birds. The total number of 396 birds were identified in the diet of foxes, and 62 in the diet of martens.

To compare the dietary overlap of foxes and martens, or the diet of either species in different seasons, years, etc., the Morisota (1959) index was used, modified by Horn (1966):

$$
C=\frac{2 \sum_{i=1}^{n} x_{i} y_{i}}{\sum_{i=1}^{n} x_{i} \sum_{i=1}^{n} y_{i}}
$$

where $C$ is dietary overlap ranging from 0 to 1 (1 means an identical food composition), $x_{i}$ and $y_{i}$ denote the percentage of a given food component in the diet of foxes and martens, the percentage of a given food component in two different seasons in the diet of the same species.

\section{RESULTS}

\subsection{Food Composition}

The food of foxes comprised about equal proportions (from 26 to $33 \%$ by weight) of three prey items: small mammals, hares and birds (Table 1). Supplementary food consisted of fruits and carrion. Among small mammals the common vole dominated, accounting for about two-thirds of this prey biomass. Among birds there were mostly domestic hens. Game birds (pheasants and partridges) accounted for about 8\% of the food consumed (Table 1).

The diet of martens was more diversified than that of foxes. In addition to small mammals, birds, and hares, an important component of their food were fruits (Table 1). In contrast to the diet of foxes, carrion was a less important component of marten diet, whereas insects were more important. The small mammal component was dominated by the bank vole (ca $52 \%$ of the biomass of small mammals consumed). The 
common vole was of secondary importance ( $28 \%$ of small mammals). Among birds, pheasants and domestic hens predominated by weight (Table 1).

Table 1

Diet composition of foxes and martens in percentage by weight.

\begin{tabular}{lrr}
\hline Food item & Fox & Marten \\
\hline Small mammals total & 33.27 & 29.10 \\
Microtus arvalis & 21.50 & 8.04 \\
Microtus oeconomus & 1.99 & 0.53 \\
Pitymys subterraneus & 0.89 & 0.47 \\
Clethrionomys glareolus & 4.18 & 15.25 \\
Apodemus sp. & 2.00 & 1.58 \\
Sciurus vulgaris & 0.12 & 0.20 \\
Talpa europea+Sorex sp. & 0.87 & 1.70 \\
Lagomorpha & 25.86 & 7.95 \\
Carrion total & 8.22 & 3.28 \\
Capreolus capreolus & 1.20 & 2.15 \\
Sus scrofa & 1.91 & \\
Canis familiaris & 0.91 & 0.07 \\
Felis catus & 0.51 & 0.05 \\
Birds total: & 25.51 & 19.08 \\
Columba sp. & 2.71 & 1.91 \\
Gallus domesticus & 13.46 & 4.74 \\
Phasianus colchicus & 7.31 & 5.84 \\
Perdix perdix & 0.72 & 0.38 \\
Small birds & 0.09 & 1.09 \\
Frogs & 0.03 & 0.18 \\
Insects & 0.59 & 2.95 \\
Fruits & 6.49 & 37.15 \\
Others (foil, bark, straw, stick, etc.) & 0.03 & 0.31 \\
\hline
\end{tabular}

\subsection{Multi-annual Variation in the Diet}

In 1978-1985, the proportion of small mammals in the diet of foxes largely fluctuated (Fig. 1). In 1981, the density of the common vole near Rogów increased up to 80 individuals per hectare (Goszczyński, 1985). In 1983, the density of the bank vole markedly increased in forests of the study area as a result of a high mast fall, mostly acorns, in the preceding year (Babińska-Werka, pers. comm.). These two occurrences promoted a functional response of foxes. They preyed upon common vole at a highest rate at the time of their mass appearance, that is, in the autumn of 1981 (Fig. 1). The next rise in the consumption of small mammals occurred in 1983, when the bank vole accounted for about $31 \%$ of the total biomass of small mammals in the diet, and the common vole comprised about a half of the biomass of this group. Avian prey in the diet of foxes fluctuated irregularly, and in a compensatory way 
relative to small rodents (Fig. 1). A negative correlation was found between the consumption of small mammal prey, on the one hand, and hare and bird prey, on the other, by foxes over the study period ( $r=$ $=-0.64, p=0.001$ and $r=-0.74, p<0.001$, respectively(, (Fig. 2 and 3).

Small mammals


Fruits
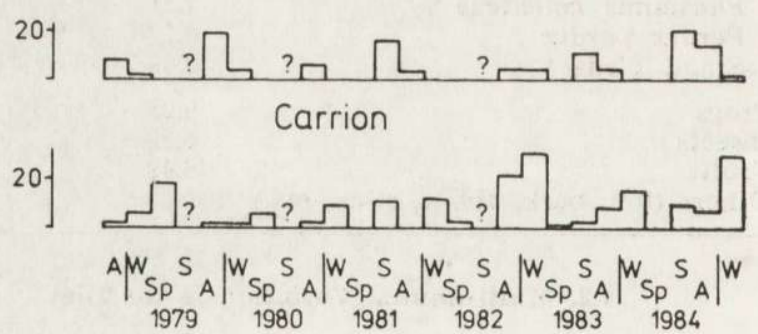

Fig. 1. Changes in the proportions (percentage by weight) of different components in the diet of foxes in 1978-1985. (W - winter, Sp - spring, S - summer, A - autumn).

A similar correlation was found between the consumption of the common vole, the dominant prey in the group of small mammals, and the consumption of hares or birds by foxes $(r=-0.62,0.005>p>0.001$ and $r=-0.66, p<0.001$, respectively). No significant correlation was found between the consumption of birds and hares by foxes $(r=0.16, p>0.2)$. The consumption of two groups of food, hares and fruits, by foxes was limited to some seasons (Fig. 1).

In the diet of martens, only the consumption of small mammals was not seasonal (Fig. 4). Martens showed a remarkable response to an 


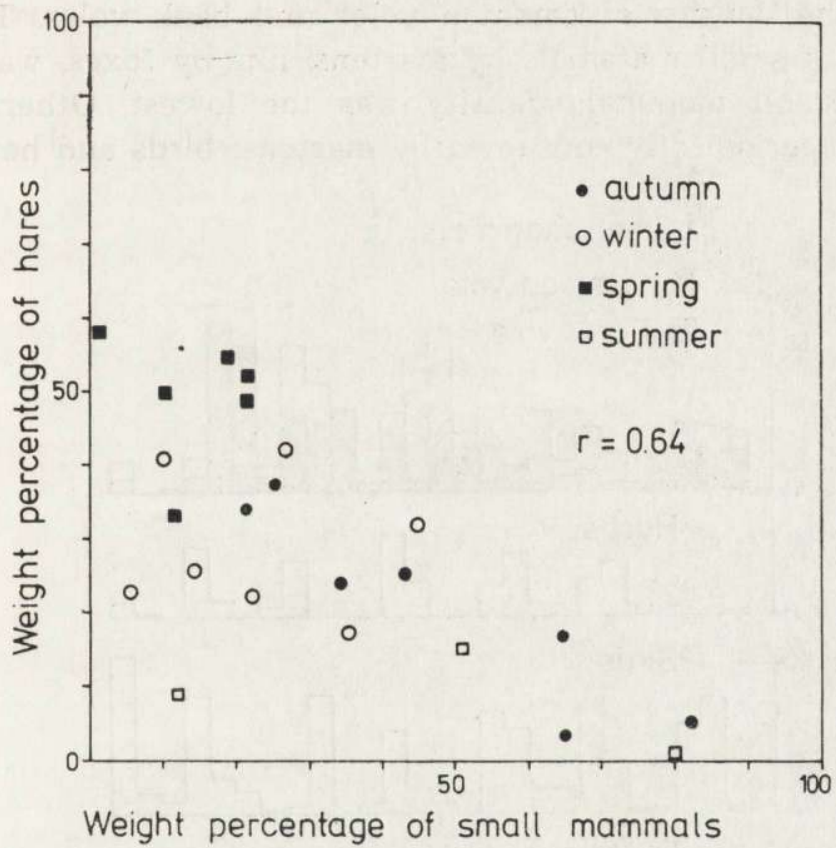

Fig. 2. Correlation between the consumption of small mammals and hares by foxes.

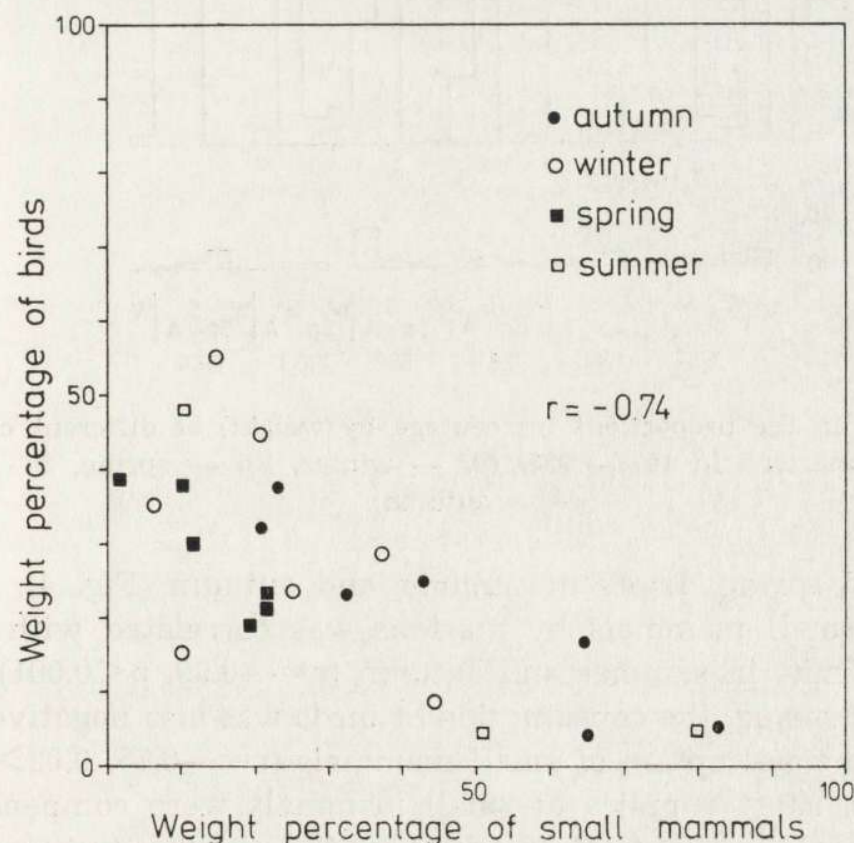

Fig. 3. Correlation between the consumption of small mammals and birds by foxes. 
increase in the density of common voles and bank voles. The lowest consumption of small mammals by martens, like by foxes, was noted in 1984, when small mammals density was the lowest. Other prey categories were periodically consumed by martens: birds and hares mostly

Small mammals
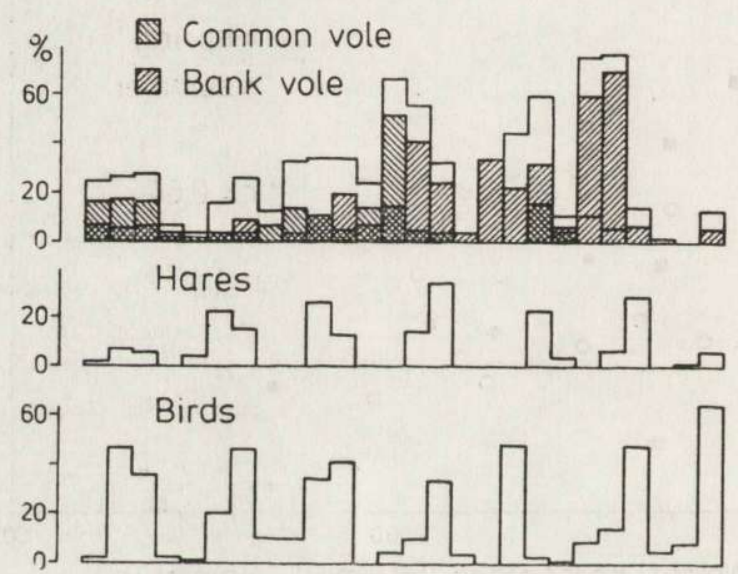

Fruits

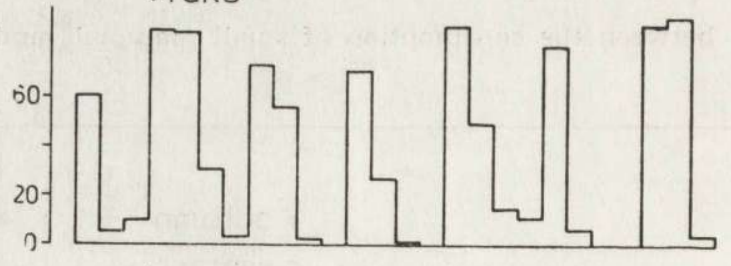

Insects

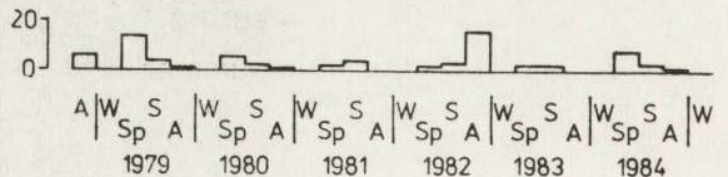

Fig. 4. Changes in the proportions (percentage by weight) of different components in the diet of martens in 1978-1985. (W - winter, Sp - spring, S - summer, A - autumn).

in winter and spring, fruits in summer and autumn (Fig. 4). The consumption of small mammals by martens was correlated with the consumption of fruits in summer and autumn ( $r=-0.99, p<0.001)$, (Fig. 5). In winter and spring, the consumption of birds was also negatively correlated with the consumption of small mammals $(r=-0.75,0.02>p>0.01)$, (Fig. 6). Thus, short supplies of small mammals were compensated for by an increased consumption of fruits in the summer-autumn periods and birds in the winter-spring periods. 


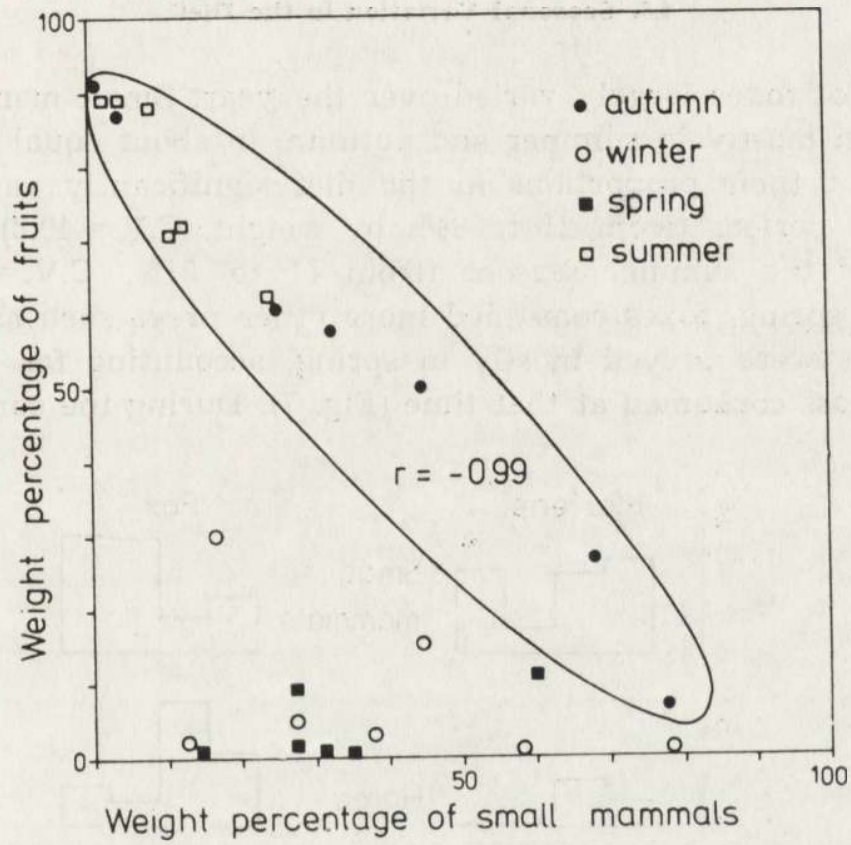

Fig. 5. Correlation between the consumption of small mammals and fruits by martens.

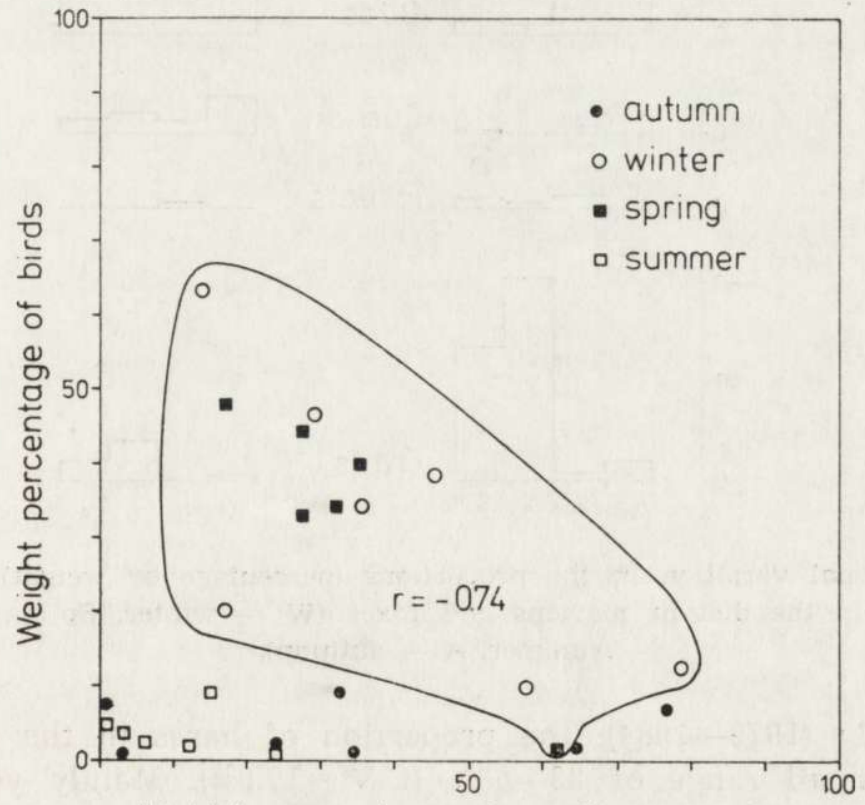

Weight percentage of small mammals

Fig. 6. Correlation between the consumption of small mammals and birds by martens. 


\subsection{Seasonal Variation in the Diet}

The diet of foxes largely varied over the year. Small mammals were preyed upon mostly in summer and autumn, in about equal proportions (Fig. 7). But their proportions in the diet significantly varied during the autumn periods (from 21 to $84 \%$ by weight, C.V. $=49.8$ ). The same was true of the summer seasons (from 11 to $51 \%$, C.V. $=72.4 \%$ ). In winter and spring, foxes consumed more other preys such as hares and birds. Hares were preyed mostly in spring, accounting for almost half of the biomass consumed at that time (Fig. 7). During the spring seasons

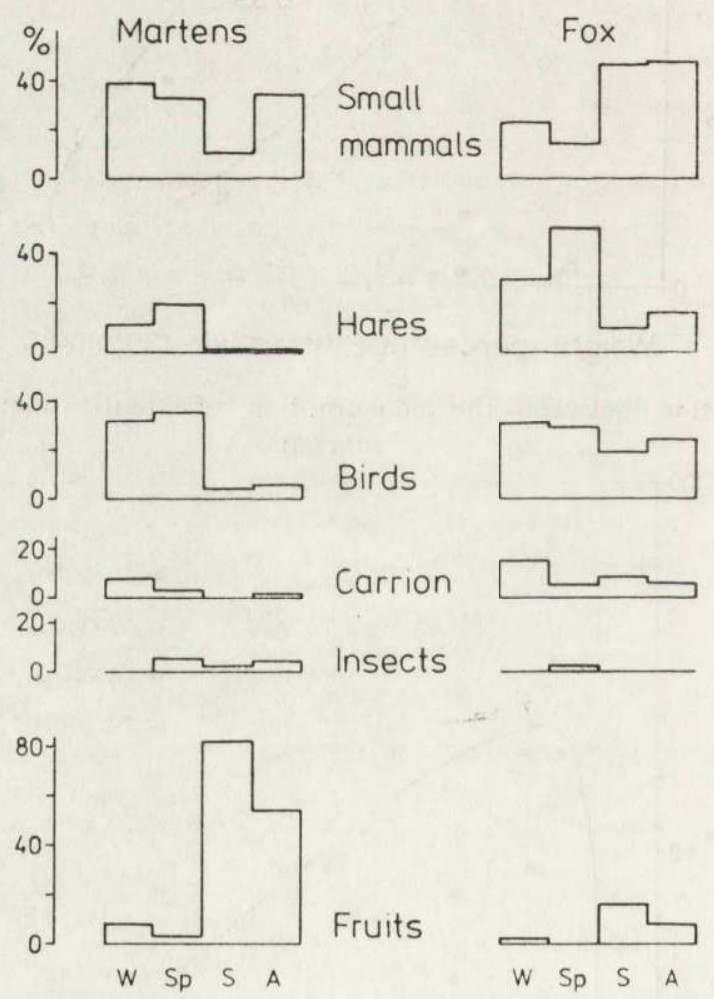

Fig. 7. Seasonal variation in the proportions (percentage by weight) of different components in the diet of martens and foxes (W - winter, $\mathrm{Sp}-$ spring, $\mathrm{S}-$ summer, A - autumn).

under study (1979-1984), the proportion of hares in the diet varied within a small range of $33-58 \%$ (C.V. $=17.9 \%)$. Mainly young hares were caught, as indicated by comparison of the sizes of incisors found in feces of foxes. In winter seasons the consumption of hares was more variable $(\mathrm{C} . \mathrm{V} .=29.4 \%)$. During severe winters with deep snow cover 
(1978/1979 and 1984/1985), the proportion of hares in the diet was higher than in mild winters $(41.7 \%$ versus $24.5 \%$, respectively, $t=3.96$, $0.02>p>0.01$ ). Birds were preyed upon in about equal proportions in spring and winter (Fig. 7). Their consumption in winter largely varied (C.V. $=55.0 \%$ ). The mean proportion of birds during severe, snowy winters was lower than during mild winters $(20 \%$ versus $35 \%, p>0.05$ ), though the proportion of birds largely varied during mild winters (see Fig. 1). In spring, the proportion of bird prey was less variable (C.V.= $=28 \%$ ).

The consumption of carrion was important only in winter, in the other seasons it accounted for $5-8 \%$ of the diet. Foxes fed on fruits (mainly apples and pears) in summer and autumn but in small amounts (Fig. 7). Traces of fruits were also found in winter.

Seasonal changes in the diet of martens were somewhat similar to those typical of foxes, though the total consumption was different (Fig. 7). This was true for all prey groups, except for small mammals.

Table 2

Similarity in the diets of foxes and martens in different seasons $(V-V u l p e s$ vulpes, $M-$ Martes sp.)

\begin{tabular}{lccccc}
\hline Variables & & Winter & Spring & Summer & Autumn \\
\hline Number of seasons & $V$ & 7 & 6 & 3 & 7 \\
& $M$ & 7 & 6 & 6 & 7 \\
Number of comparisons & $V$ & 21 & 15 & 3 & 21 \\
& $M$ & 21 & 15 & 15 & 21 \\
Mean dietary overlap & $\mathrm{V}$ & 0.78 & 0.93 & 0.54 & 0.78 \\
& $M$ & 0.69 & 0.81 & 0.98 & 0.70 \\
\hline
\end{tabular}

Except in summer, small mammals were preyed upon in similar proportions, accounting for about one-third of the food biomass consumed. Variation in the consumption of this group was high (C.V. $=46.8 \%$, $59.3 \%$, and $84.2 \%$ for winter, spring, and autumn, respectively). The highest proportion of the common vole (about $14 \%$ of the diet by weight) was noted in autumn, when agricultural treatments, mostly plowing, forced these animals into forests. But the bank vole was intensively exploited by martens, and its proportion in the diet varied between 17 and $23 \%$ of the total food consumed, except in summer. The highest consumption of hares and birds occurred in winter and spring, like in the case of foxes (Fig. 7). In spring, martens readily searched for eggs of birds. On the average, about $16 \%$ of the samples comprised egg shells. In summer and autumn, the diet was dominated by fruits (in summer sweet cherry, bird cherry, sour cherry, and raspberry, in autumn, pears, apples, and garden plum), and the proportion of the animal food dropped 
below $50 \%$ (Fig. 7). The lowest variation in fruit consumption was noted in summer (the proportion of fruits varied from 71 to $90 \%$, C.V. $=9.9 \%$ ).

A comparison of the total diet (including all the main food components: small mammals, hares, carrion, insects, and fruits) in different seasons shows that the highest similarity in the diet of foxes occurred in spring and in the diet of martens in summer (Table 2).

A comparison of the diet of these two predators in different seasons confirmed a visual impression (see Fig. 7) that the diet of martens was more similar to the diet of foxes in winter and spring (dietary overlap of 0.87 and 0.78 , respectively) than in summer and autumn $(C=0.38$ and 0.61 , respectively).

\section{DISCUSSION}

We might expect that in western Poland, where typically the densities of the common vole are high, the diet of opportunistic predators: martens and foxes would differ from that in other areas.

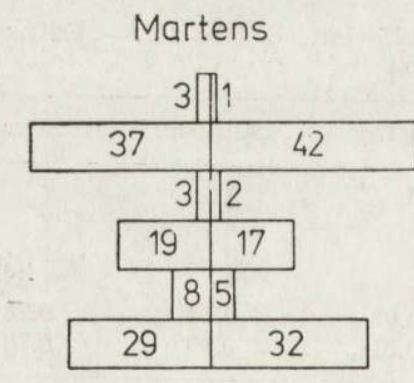

Central Poland West Poland
(This study) (Goszczyniski.
1976)
Fox

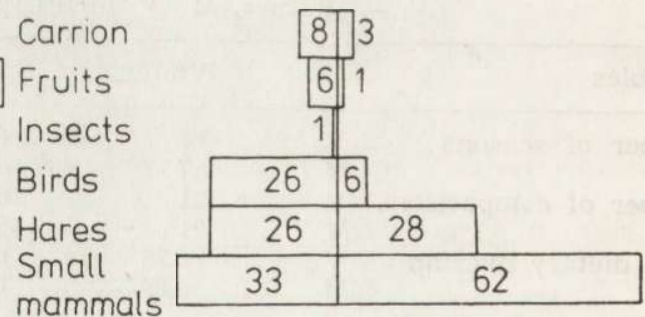

Central Poland West Poland

(This study) (Goszczyniski, 1974:

Goszczyniski,et al , 1976)

Fig. 8. Comparison of the diet of martens and foxes in central and western Poland (figures denote percentage by weight of individual food components).

However, diet of martens in the region of Rogów (central Poland) was very similar to that found in Poznan District (western Poland) (Fig. 8), where the food of predatory mammals was analysed by the same methods (Goszczyński, 1976). The index of dietary overlap (C) for martens in two different regions calculated for the main diet components enumerated in Fig. 8 is very high, namely 0.99. This similarity was maintained during all the seasons ( 0.88 in winter, 0.94 in spring, and 0.99 in summer and autumn). The present data were also compared with the results reported by Rzebik-Kowalska (1972), who analysed 
the food of pine martens on the basis of their stomach contents throughout Poland. According to her data, the percentage by weight of different food types in winter was: small mammals (hedgehogs excluded) 42.1, Lagomorpha 7.5 , carrion 13.5 , birds 26.2 , insects zero, plant 3.0 . The respective values for the Rogów region were: $38.8,11.2,8.4,32.6,0.1$, and 8.5. In this case $C=0.98$.

Differences in the diet between central Poland (Rogów) and western Poland are practically limited to proportions of individual species in the group of small mammals. In western Poland, the common vole was dominant, accounting for $76 \%$ of this group (Goszczyński, 1976). In central Poland, the bank vole predominated (52.4\%). It has been found that the consumption of common voles largely varied during the periods analysed, but the variation of consumption was higher in central Poland (C.V. $=133.9 \%$ versus $65.3 \%$ ). Moreover, the seasonality of utilizing the plant and animal food was more pronounced in central Poland. Smaller differences in the consumption of plant and animal food in the summerautumn and winter-spring periods were presumably largely due to climatic conditions in western Poland. Thin snow cover, or its total absence in some years, permits martens the utilization of fruits for most of the winter period.

The diet of foxes in central Poland markedly differed from that in western Poland (Fig. 8). The index of dietary overlap in the two regions was 0.82 , and in particular seasons its values were as follows: 0.70 in winter, 0.97 in spring, 0.85 in summer-autumn. Characteristically, at high populations of rodents in cropland (Goszczyński, 1974; Goszczyński et al., 1976), variation in the proportion of small mammals in the diet was smaller there than in central Poland (C.V. $=47.2 \%$ versus $73.6 \%$ ) Variation in the proportion of common voles in the diet at the two localities was similar to variation in the total proportion of small mammals (C.V. $=46.7 \%$ in western Poland and C.V. $=93.5 \%$ in central Poland). In western Poland, foxes consumed few birds because the density of game birds was low and domestic fowl was well protected by farmers. Thus the only food compensating for insufficient supply of small rodents was hares (Goszczyński, 1974; Goszczyński et al., 1976; Pielowski, 1976). The proportion of hares in the diet of foxes in western Poland largely varied from 6 to $75 \%(C . V .=66 \%)$, whereas in central Poland this variation was lower (C.V. $=52 \%)$.

A comparison of the mean proportions of different groups in the diet from year to year shows that in western Poland all the categories, except for small mammals, were more variable (small mammals: C.V.= $=32.1 \%$ in western Poland and C.V. $=25.9 \%$ in central Poland; hares: $43.3 \%$ and $12.0 \%$; birds: $38.8 \%$ and $25.9 \%$; carrion $79.5 \%$ and $52.2 \%$; 
fruits: $200 \%$ and $45.6 \%$, respectively). A comparison of the total diet composition in particular years shows, that the diet in western Poland was a little more variable than in central Poland $(C=0.93$ and 0.91 , respectively).

Seasonal differences in the diet composition were more pronounced in central Poland ( $C$ for winter and spring was 0.90 , for winter and summer-autumn 0.67 , for spring and summer-autumn 0.68). The respective values for western Poland were $0.98,0.83$, and 0.75 (based on data from Goszczyński, 1974; and Goszczyński et al., 1976). This shows that high densities of the common vole reduced seasonal differences. Seasonal variation in the diet was lowest in western Poland in the summer-autumn period, and in central Poland in spring.

The basic differences in the diet of martens and foxes between areas with high densities of the common vole and moderate or low densities of this species can be summarized as follows:

1. Differences in the density of common voles in these two areas result in differences in the consumption of this species by foxes and martens.

2. In areas of high densities of common voles, variation in their proportion in the diet of martens and foxes is lower. The proportion of other groups in the diet is more variable than in areas with moderate numbers of common voles in the case of foxes or differences are not significant in the case of martens.

3. In areas of low common vole densities, foxes compensate for the shortage of this prey mostly by consuming other food types (birds, carrion, fruits). Martens in this situation only switch the proportions within the group of small mammals. In place of common voles they prey upon other rodents, and the consumption of other prey types remains almost unchanged. As a result, in the two areas the diet of martens is very similar, whereas the diet of foxes is different.

4. Year-to-year variation in the diet of foxes is lower in the areas of low common vole densities. For martens differences were not significant.

5. Seasonal differences in the diet of foxes are high in areas of low common vole densities. The diet of martens is also more seasonal in the areas of low common vole densities but this seems to be mostly due to climatic differences. The diet of foxes in the areas of low common vole densities shows the highest similarity in spring seasons, and in the areas of high common vole densities it is most similar in springautumn periods. This may be a symptom of specialization of foxes in preying upon small mammals.

Although the two species are considered to be opportunistic preda- 
tors, the data collected here show that martens are more traditional opportunists than foxes, the latter being more flexible in their diet composition.

\section{REFERENCES}

1. Goszczyński J., 1974: Studies on the food of foxes. Acta theriol., 19: 1-18.

2. Goszczyński J., 1976: Composition of the food of martens. Acta theriol., 21: $527-534$

3. Goszczyński J., 1985: Wpływ strukturalnego zróżnicowania krajobrazu ekologicznego na przebieg interakcji drapieżnik-ofiara. Rozprawy Naukowe i Monografie SGGW-AR, 46: 1-80. [In Polish with English summary].

4. Goszczyński J., Ryszkowski L. \& Truszkowski J., 1976: The role of the European hare in the diet of predators. [In: "Ecology and management of European hare populations", Eds. Pielowski Z. \& Pucek Z.] 127-133. PWRiL. Warszawa.

5. Horn M. S., 1966: Measurement of "overlap" in comparative ecological studies. Am. Nat., 100: 419-424.

6. Lockie J. D., 1959: The estimation of the food of foxes. J. Wildl. Manage., 23: $224-227$.

7. Morisota M., 1959: Measuring of interspecific association and similarity between communities. Mem. Fas. Sci. Kyushu Univ., 3: 65-80.

8. Pielowski Z., 1976: The role of foxes in the reduction of the European hare population. [In "Ecology and management of European hare populations", Eds. Pielowski Z. \& Pucek Z.]: 135-148. PWRiL. Warszawa.

9. Rzebik-Kowalska B., 1972: Badania nad pokarmem ssaków drapieżnych w Polsce. Acta zool. Cracoviensis, 17: 415-506.

Accepted, March 23, 1986

Jacek GOSZCZYŃSKI

\section{SKEAD POKARMU LISOW I KUN W POLSCE SRODKOWEJ}

\section{Streszczenie}

Skład pokarmu lisów i kun badano na tym samym terenie (okolice Rogowa, środkowa Polska). W pokarmie lisów mniej więcej równy udział (ok. 26-33\% wagowo) miały trzy składniki: drobne ssaki, ptaki i zające (Tabela 1). W pokarmie kun oprócz drobnych ssaków, ptaków i zajęcy istotne znaczenie miały również owoce (Tabela 1). Stwierdzono, że wzrost liczebności gryzoni wywoływał reakcję funkcjonalną ze strony lisów i kun (Ryc. 1 i Ryc. 4). Występowały reakcje kompensacyjne między spożyciem drobnych ssaków a konsumpcją zajęcy i ptaków w przypadku lisów (Ryc. 2 i Ryc. 3) oraz między spożyciem drobnych ssaków a konsumpcją owoców i ptaków w przypadku kun (Ryc. 5 i Ryc. 6). W przypadku 
lisów największym podobieństwem odznaczały się sezony wiosenne, natomiast pokarm kun był najbardziej podobny w sezonach letnich (Tabela 2).

Różnice sezonowe w pokarmie kun i lisów były ostro zaznaczone (Ryc. 7). Porównanie składu pokarmu drapieżników na badanym terenie $\mathrm{z}$ pokarmem na obszarach o wysokim zagęszczeniu nornika (Polska zachodnia) wykazało duże podobieństwo diety w przypadku kun i duże różnice w przypadku lisów. Stwierdzono, że na badanym terenie udział nornika zwyczajnego był niższy niż w pokarmie drapieżników na obszarach Polski zachodniej i podlegał silniejszym wahaniom. Kuny kompensują niedobór nornika intensywniejszym spożyciem innych gatunków gryzoni podczas gdy lisy intensywniej zjadają ptaki, padlinę i owoce 